\title{
Pengaruh konsentrasi cobalt chromium pada uji hemolisis sebagai implan gigi
}

\author{
Yosaphat Bayu Rosanto*, W. Widjiono**, Teguh Triyono*** \\ *Departemen Bedah Mulut dan Maksilofasial, Fakultas Kedokteran Gigi, Universitas Gadjah Mada, Yogyakarta, Indonesia \\ ${ }^{* *}$ Departemen IImu Biomaterial Kedokteran Gigi, Fakultas Kedokteran Gigi, Universitas Gadjah Mada, Yogyakarta, Indonesia \\ ***Departemen Patologi Klinik, Fakultas Kedokteran, Universitas Gadjah Mada, Yogyakarta, Indonesia \\ *JI Denta No 1, Sekip Utara, Yogyakarta, Indonesia; e-mail: yosaphatbr@ugm.ac.id
}

Submisi: 12 Juni 2015; Penerimaan: 16 Mei 2016

\begin{abstract}
ABSTRAK
Implan gigi digunakan untuk mengganti gigi yang hilang untuk dan dapat mengembalikan fungsi gigi. Cobalt chromium memiliki sifat-sifat yang memenuhi persyaratan sebagai material implan. Material yang diimplankan dalam tubuh harus memiliki sifat biokompatibilitas. Salah satu sifat biokompatibilitas yang harus dimiliki material yang diimplankan dalam tubuh adalah sifat hemokompatibilitas. Sifat hemokompatibilitas dapat diketahui dengan uji hemolisis. Penelitian ini bertujuan untuk mengetahui ada/tidaknya pengaruh logam cobalt chromium sebagai material implan gigi terhadap hemolisis pada darah kelinci. Penelitian ini dilakukan menggunakan sampel darah yang didapat dari kelinci (Oryctolagus cuniculus) yang dibagi menjadi 3 kelompok, yaitu perlakuan, kontrol positif dan negatif. Bahan penelitian yang diuji adalah cobalt chromium Remanium ${ }^{\circledR}$ GM 800 produksi Dentaurum. Kontak darah dengan bahan uji dilakukan menggunakan uji hemolisis ASTM-F075. Hasil penelitian menunjukkan material logam cobalt chromium tidak menimbulkan hemolisis pada konsentrasi $2,5 \%, 5 \%$, dan $10 \%$, menimbulkan hemolisis ringan pada konsentrasi $20 \%$, dan hemolisis pada konsentrasi $40 \%$ dan $80 \%$. Kesimpulan dari penelitian ini adalah perbedaan konsentrasi logam cobalt chromium berpengaruh secara signifikan terhadap persentase hemolisis.
\end{abstract}

Kata kunci: coblat chromium, implan gigi, hemolisis, hemokompatibilitas

ABSTRACT: The effect of concentration of cobalt chromium in hemolysis test for dental implant. Dental implants are used to replace tooth/teeth loss and its function. Cobalt chromium has ideal characteristics to be made as dental implants material. It is required that the material to be implanted must be biocompatible with cells and tissues. One of biocompatibility characteristics is hemocompatibility. Hemocompatibility of materials can be observed with hemolysis test. Thus the purpose of this research is to know whether cobalt chromium as dental implants material affect the hemolysis of rabbit blood or not. This research was done with rabbit blood (Oryctolagus cuniculus) and devided into 3 groups (treatment, positive and negative control). The tested material was cobalt chromium Remanium $\otimes$ GM 800 , a product from Dentaurum. The contact between blood and material was done with ASTM-F075 hemolysis test. Cobalt chromium was not hemolytic at 2,5\%, 5\%, and $10 \%$ of concentration, slightly hemolytic at $20 \%$ of concentration, and hemolytic at $40 \%$ and $80 \%$ of concentration. The conclusion of this research was variety of concentration of cobalt chromium affected hemolysis percentage significantly.

Keywords: cobalt chromium, dental implants, hemolysis, hemocompatibility

\section{PENDAHULUAN}

Implan gigi merupakan salah satu alternatif protesa gigi untuk mengganti gigi yang hilang dan mengembalikan fungsi mastikasi, estetis, fonasi, dan perlindungan jaringan pendukung gigi secara ideal. ${ }^{1}$ Material logam implan gigi harus bioinert dan tidak melepaskan ion logam ke jaringan tubuh. Tanda-tanda keberhasilan implan gigi adalah tidak ada mobilitas, radiolusensi, komplikasi pada jaringan lunak, dan kehilangan tulang. Material yang biokompatibel mengalami kontak dengan jaringan dan cairan tubuh tanpa menimbulkan efek yang berbahaya. ${ }^{2,3}$
Cobalt chromium adalah logam campuran berbahan dasar cobalt dengan campuran chromium yang dapat memenuhi persyaratan sebagai material implan gigi. Keunggulan dari logam cobalt chromium adalah resisten terhadap korosi, dapat dipolis dengan baik, ringan, keras, kuat, kaku, dan relatif ekonomis. ${ }^{3,4,5}$ Cobalt chromium yang digunakan pada penelitian ini adalah Remanium ${ }^{\circledR}$ GM 800 produksi Dentaurum, dengan komposisi cobalt $63,3 \%$, chromium $30 \%$, molibdenum $5 \%$, nikel $0,25 \%$, karbon $0,22 \%$, besi $0,2 \%$, dan mangan, karbon, silika, dan tungsten kurang dari $1 \%{ }^{6}$ 
Implan gigi harus memiliki sifat hemokompatibilitas karena ditanamkan di dalam tubuh dan akan berkontak dengan darah. ${ }^{7}$ Uji hemolisis direkomendasikan untuk semua alat dan material kedokteran yang berkontak dengan darah. Uji ini mengukur kerusakan terhadap sel darah merah ketika terpapar oleh suatu material atau ekstraknya. ${ }^{8,9}$ Fasching dkk., meneliti sifat hemolisis material nikel-titanium-cobalt untuk aplikasi alat-alat kedokteran. Hasil penelitian tersebut menunjukkan adanya hemolisis yang disebabkan oleh ion nikel, titanium dan cobalt yang terlepas. ${ }^{10}$ Penelitian sifat hemolisis material cobalt chromium sebagai bahan implan gigi belum pernah dilakukan.Penelitian ini bertujuan untuk mengetahui ada/tidaknya pengaruh logam cobalt chromium sebagai material implan gigi terhadap hemolisis pada darah kelinci.

\section{METODE PENELITIAN}

Ethical clearance dengan nomor KE/ FK/929/EC diperoleh dari Komisi Etik Penelitian Kedokteran dan Kesehatan Fakultas Kedokteran Universitas Gadjah Mada Yogyakarta (Medical and Health Research Ethics Comittee (MHREC). Cobalt chromium (Remanium ${ }^{\circledR}$ GM 800 produksi Dentaurum) dalam sediaan serbuk dilakukan sterilisasi dengan autoclave \pm 15 menit. Kelompok kontrol positif menggunakan SWFI 3,5 ml, kelompok kontrol negatif menggunakan PBS $3,5 \mathrm{ml}$, dan kelompok perlakuan menggunakan suspensi cobalt chromium 3,5 $\mathrm{ml}$ dengan konsentrasi 2,5\%, 5\%, $10 \%, 20 \%, 40 \%$, dan $80 \% \mathrm{~b} / \mathrm{v}$, semuanya diletakan dalam centrifuge tube BIOLOGYX ${ }^{\circledR} 15 \mathrm{ml}$ dan dibuat 3 replikasi. ${ }^{11}$

Darah kelinci (Oryctolagus cunniculus) diambil sebanyak $10 \mathrm{ml}$ melalui vena telinga, kemudian dimasukan ke dalam tabung EDTA. ${ }^{11}$ Sampel darah yang diperoleh ditambahkan masingmasing $0,5 \mathrm{cc}$ darah ke centrifuge tube yang dibagi menjadi 3 kelompok, yaitu kelompok kontrol positif, negatif, dan perlakuan (konsentrasi 2,5\%, $5 \%, 10 \%, 20 \%, 40 \%$, dan $80 \%)$. Tabung-tabung tersebut dipasangkan pada rotator, kemudian dimasukan ke dalam inkubator $37{ }^{\circ} \mathrm{C}$. Rotator dihidupkan dengan kecepatan 10x putaran/menit, selama 3 jam. Setelah 3 jam diputar dalam suhu
$37{ }^{\circ} \mathrm{C}$, tabung diambil lalu dipisahkan plasmanya dengan dilakukan sentrifugasi dengan sentrifugator 3000 rpm selama 10 menit. Setelah plasma dan endapan terpisah, $\mathrm{Hb}$ plasma diukur menggunakan hematology analyzer. ${ }^{11}$

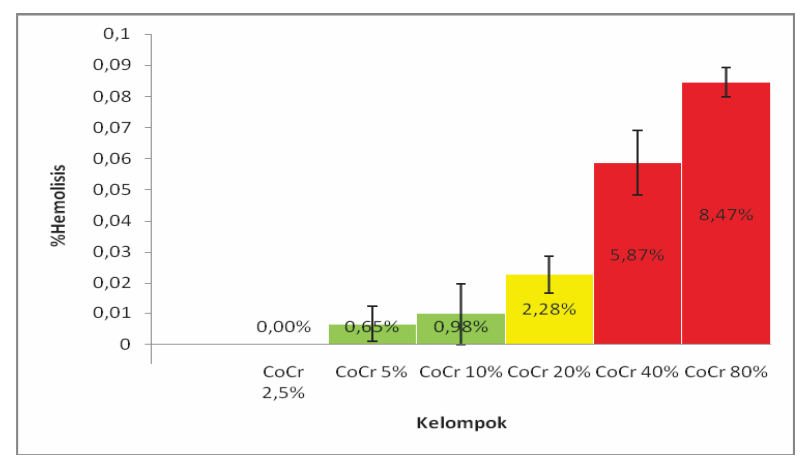

Gambar 1. Grafik rerata dan standar deviasi hasil perhitungan persentase hemolisis

Tabel 1. Rerata dan standar deviasi persentase hemolisis

\begin{tabular}{cccc}
\hline Sampel & Rerata & Standar Deviasi & $\mathrm{n}$ \\
\hline CoCr $2,5 \%$ & $0,00 \%$ & $0,00 \%$ & 3 \\
CoCr 5\% & $0,65 \%$ & $0,57 \%$ & 3 \\
CoCr 10\% & $0,98 \%$ & $0,99 \%$ & 3 \\
CoCr $20 \%$ & $2,28 \%$ & $0,59 \%$ & 3 \\
CoCr $40 \%$ & $5,87 \%$ & $1,04 \%$ & 3 \\
CoCr $80 \%$ & $8,47 \%$ & $0,47 \%$ & 3 \\
\hline
\end{tabular}

Tabel 2. Persebaran data uji hemolisis berdasarkan indeks hemolisis

\begin{tabular}{cccc}
\hline Sampel & $\begin{array}{c}\text { Non } \\
\text { Hemolisis } \\
0-2 \%\end{array}$ & $\begin{array}{c}\text { Hemolisis } \\
\text { Ringan } \\
2-5 \%\end{array}$ & $\begin{array}{c}\text { Hemolisis } \\
>5 \%\end{array}$ \\
\hline CoCr $2,5 \%$ & 3 & - & - \\
CoCr $5 \%$ & 3 & - & - \\
CoCr $10 \%$ & 3 & - & - \\
CoCr $20 \%$ & 2 & 1 & - \\
CoCr $40 \%$ & - & 1 & 2 \\
CoCr $80 \%$ & - & - & 3 \\
\hline Jumlah & 11 & 2 & 5 \\
\hline Persentase & $61,11 \%$ & $11,11 \%$ & $27,89 \%$ \\
\hline
\end{tabular}

\section{HASIL PENELITIAN}

Persentase hemolisis terlihat meningkat seiring dengan peningkatan konsentrasi cobalt chromium (Gambar 1). Terdapat 3 kelompok sampel yang tidak menunjukkan hemolisis (sampel dengan konsentrasi $2,5 \%, 5 \%$, dan $10 \%$ ). Sampel cobalt chromium 20\% menunjukkan rerata hemolisis 
$2,28 \%$ (hemolisis ringan), namun secara rinci terdapat 2 sampel yang menunjukkan nilai rerata non hemolisis $(1,94 \%)$ dan 1 sampel menunjukkan nilai rerata hemolisis ringan (2,97\%). Sampel cobalt chromium $40 \%$ menunjukkan rerata hemolisis $5,87 \%$ (hemolisis), namun secara rinci terdapat 1 sampel yang menunjukkan nilai rerata hemolisis ringan $(4,85 \%)$ dan 2 sampel menunjukkan rerata hemolisis $(5,83 \%$ dan $6,93 \%)$.

Hasil analisis Kruskall-Wallis dengan nilai $p$ $=0,009$ menunjukkan bahwa terdapat perbedaan persentase hemolisis yang signifikan antara kelompok perlakuan, kontrol negatif, dan positif. Perbedaan kelompok tersebut dapat dilihat dengan melakukan analisis Mann-Whitney. Hasil uji MannWhitney terhadap persentase hemolisis antar kelompok perlakuan menunjukkan bahwa semua kelompok menunjukkan perbedaan yang signifikan $(p<0,05)$, kecuali kelompok A-B, A-C, dan B-C ( $p$ $>0,05)$.

\section{PEMBAHASAN}

Penelitian ini dilakukan menggunakan darah yang diambil langsung dari kelinci dan langsung diberikan perlakuan, sehingga kondisi darah masih dalam kondisi yang baik dan segar. Interaksi permukaan logam dengan darah pada penelitian ini terjadi ketika darah dan logam cobalt chromium di dalam centrifuge tube dirotasikan dengan rotator sehingga terjadi simulasi aliran darah dan kontak eritrosit dengan logam cobalt chromium. Hasil penelitian menunjukkan bahwa suspensi logam cobalt chromium dengan konsentrasi $40 \%$ dan $80 \%$ dapat menimbulkan hemolisis pada darah kelinci. Kontak antara logam dengan eritrosit memiliki efek yang sifnifikan terhadap pelepasan hemoglobin dari eritrosit. ${ }^{12}$

Hal-hal yang dapat menyebabkan hemolisis adalah defek eritrosit, infeksi, obat, zat kimia, transfusi, antibodi, kerja limpa berlebihan, toksik, dan mekanis.Gaya gesek eritrosit dengan material sebesar $150 \mathrm{~Pa}$ (1500 dynes/cm²) dapat menyebabkan hemolisis. ${ }^{13}$ Hasil penelitian yang ditunjukkan pada Tabel 1 terdapat kecenderungan peningkatan persentase hemolisis dengan peningkatan konsentrasi cobalt chromium. Hal ini dapat terjadi karena semakin tinggi konsentrasi suspensi, semakin banyak jumlah serbuk logam cobalt chromium yang digunakan, sehingga semakin banyak gaya gesek yang terjadi antara eritrosit dengan logam cobalt chromium. Hasil penelitian yang ditunjukkan pada Tabel 2, pada konsentrasi cobalt chromium 20\%, terdapat satu sampel yang menunjukkan persentase hemolisis ringan $(2,97 \%)$ sementara dua sampel yang lain menunjukkan persentase tidak hemolisis $(1,94 \%)$. Begitu juga pada konsentrasi cobalt chromium $40 \%$, satu sampel menunjukkan persentase hemolisis ringan $(4,85 \%)$ sementara dua sampel yang lain menunjukkan persentase hemolisis $(6,93 \%$ dan $5,83 \%$ ). Hal ini disebabkan karena proses pembuatan serbuk cobalt chromium dilakukan dengan cara pembubutan/grinding sehingga menghasilkan ukuran dan kekasaran permukaan serbuk yang kasar tidak homogen.

Konsep biokompatibilitas telah menjalani perubahan dan menjadi perhatian para penelitidalam beberapa tahun. Apabila sebelumnya perhatian biokompatibilitas adalah mengenai inertness, saat ini biokompatibilitas lebih dipertimbangkan dalam hubungan suatu material atau alat terhadap fungsi yang memuaskan. Hal ini dikarenakan, hingga saat ini masih diragukan ada material yang benar-benar inert di dalam pemakaian pada tubuh manusia. Bahkan material yang benar-benar bersifat pasif, seperti emas, telah terbukti dapat menimbulkan reaksi pada sel in vitro maupun pemakaian in vivo. Logam campuran adalah material yang relatif tidak inert. ${ }^{14}$ Logam akan melepaskan ionion ketika ditanamkan di dalam tubuh. Logam cobalt chromium akan melepaskan ion-ion Co, $\mathrm{Cr}$, Mo, Ni, C, Si, dan Fe. ${ }^{15}$ Ion-ion yang terlepas ini berbahaya bagi sel dan jaringan tubuh karena dapat menghambat sintesis DNA dan menyebabkan nekrosis sel. Hemolisis akibat material logam yang diimplankan di dalam tubuh dapat terjadi karena adanya toksisitas ion yang terlepas. ${ }^{16}$ Namun, hemolisis akibat pelepasan ion logam tidak terjadi pada penelitian ini. Hal ini ditunjukkan dengan tidak adanya hemolisis yang terjadi pada konsentrasi cobalt chromium 2,5\%, 5\%, $10 \%$ dan $20 \%$. 
Kelebihan utama logam cobalt chromium sebagai material implan gigi adalah sifat resistensi terhadap korosi.Resistensi terhadap korosi logam cobalt chromium dapat mencegah terjadinya pelepasan ion. Logam cobalt chromium yang teroksidasi akan membentuk lapisan chromium oxide $\left(\mathrm{Cr}_{2} \mathrm{O}_{3}\right)$. Lapisan chromium oxide ini akan terbentuk di permukaan logam cobalt chromium dan berperan sebagai lapisan pasif yang mencegah terlepasnya ion-ion logam. Hal ini juga ditunjang karena cobalt chromium tidak banyak mengalami retakan pada permukaannya karena densitas logam cobalt chromium yang besar, yaitu $8-9 \mathrm{~g} /$ $\mathrm{cm}^{2} .{ }^{17,18}$

Hasil penelitian ini menunjukkan bahwa cobalt chromium memiliki potensi untuk menjadi material alternatif implan gigi selain titanium karena memiliki sifat resisten terhadap korosi. Namun, penelitian lebih lanjut perlu dilakukan diantaranya pembuatan serbuk logam cobalt chromium dengan metode atomized spherical agar diperoleh permukaan yang lebih halus dan ukuran yang homogeny atau uji perendaman logam cobalt chromium pada sampel darah tanpa dilakukan rotasi.

\section{KESIMPULAN}

Variasi konsentrasi logam cobalt chromium berpengaruh secara signifikan terhadap persentase hemolisis darah kelinci. Material logam cobalt chromium Remanium $\mathrm{GM}^{\circledast} 800$ tidak menimbulkan hemolisis pada konsentrasi $2,5 \%, 5 \%$, dan $10 \%$, menimbulkan hemolisis ringan pada konsentrasi $20 \%$, dan hemolisis pada konsentrasi $40 \%$ dan $80 \%$.

\section{DAFTAR PUSTAKA}

1. Papaspyridakos $P$, Mokti M, Chen CJ, Benic GI, Gallucci GO, Chronopoulos V. Implant and prosthodontic survival rates with implant fixed complete dental prostheses in the edentulous mandible after at least 5 years: a systematic review. Clin Implant Dent Related Res. DOI: 10.1111/cid.12036. 2013.
2. Black J. Biological performances of materials. Fundamentals of Biocompatibility $4^{\text {th }} \mathrm{Ed}$. Boca Raton: Taylor \& Francis Group; 2006.

3. Schmalz G, Arenholt-Bindslev D. Biocompatibility of dental materials. SpringerVerlag Berlin Heidelberg: Berlin; 2009.

4. Anusavice KJ, Shen $\mathrm{CH}$, Rawls R. Phillips' science of dental materials. St. Louis: Elsevier Saunders; 2013.

5. Hjalmarsson L. On cobalt-chrome frameworks in implant dentistry. Goeteborg University: Goeteborg; 2009.

6. Dentaurum. Dentaurum quality worldwide unique. DENTAURUM GmbH \& Co. KG. dentaurum.de/files/989-982-20.pdf; 2014.

7. Nouri A, Hodson PD, Wen C. Biomimetic porous titanium scafolds for orthopaedics and dental application. Intech China; 2010. ISBN 978-953-307-025-4.

8. Narayan R. Biomedical Materials. Chapel Hill: Departement of Biomedical Engineering. University of North Carolina; 2009.

9. Pacific BioLabs. Assesing biocompatibility. A Guide for Medical Device Manufacturers; 2009.

10. Fasching A, Norwich D, Geiser T, Paul GW. An Evaluation of a NiTiCo Alloy and its Suitability for Medical Device Applications. JMEPEG. 2011; 20: $641-645$.

11. Hendershot MD, Corvo MF, Vistoft-Nielsen SL, Cadaret MA, Petterle SL, McCalla EN, Stevenson CM, Pohl DR. American Standard for Testing Materials (ASTM)-F075 Hemolysis. Washington: NAMSA; 2007.

12. Department of Laboratory Animal Resources. Guidelines for Blood Collection: Rodents and Rabbits. The University of Toledo: Ohio; 2011.

13. An S, Choi ES, Ahn W. Suction conditions for minimizing the production of free hemoglobin during blood salvage using an autotransfusion apparatus. Korean J Anesthesiol. 2011; 60(4): $266-271$. 
14. Brooker C. Churchill Livingstone's Mini Encyclopedia of Nursing $1^{\text {st }} \mathrm{Ed}$. Singapore: Elsevier; 2009.

15. Behl B, Papageorgiou I, Browna C, Hall R, Tipper JL, Fisher J, Ingham E. Biological effects of cobalt-chromium nanoparticles and ions on dural fibroblasts and dural epithelial cells. Biomaterials. 2013; 34: 3547 - 3558.

16. Okazakia $Y$, Gotoh E. Metal release from stainless steel, $\mathrm{Co}-\mathrm{Cr}-\mathrm{Mo}-\mathrm{Ni}-\mathrm{Fe}$ and $\mathrm{Ni}-\mathrm{Ti}$ alloys in vascular implants. J Cor Sci. 2008; 50(12): $3429-3438$.
17. Cobb AG, Schmalzreid TP. The clinical significance of metal ion release from cobaltchromium metal-on-metal hip joint arthroplasty. Proc Inst Mech Eng H. 2006; 220(2): 385 398.

18. Koudi MS, Patil SB. Prep Manual for Undergraduates. Dental Materials. New Delhi: Elsevier; 2007. 